\title{
Analysis of ecotoxic influence of waste from the biomass gasification process
}

\author{
Malgorzata Hawrot-Paw $^{1}$ (D) Adam Koniuszy ${ }^{1} \cdot$ Małgorzata Mikiciuk $^{2} \cdot$ \\ Monika Izwikow $^{1} \cdot$ Tomasz Stawicki $^{1} \cdot$ Pawel Sędlak $^{1}$
}

Received: 27 May 2016 / Accepted: 10 April 2017 / Published online: 10 May 2017

(C) The Author(s) 2017. This article is an open access publication

\begin{abstract}
The purpose of this research was evaluation of the effect of soil contamination with waste coming from biomass gasification on chosen indicators of its biological activity, growth and development of spring barley, and change of physiological parameters of the plant. Chromatographic content and basic rheological parameters of the substances under research were also analyzed. Liquid wastes, tar, and mixture of tar and engine oil were introduced to the soil in the amount of $100 \mathrm{mg} \mathrm{kg}^{-1} \mathrm{DM}$ soil. Based on the conducted research, it was ascertained that the changes in the number and activity of soil microorganisms were determined by the type of waste and its dose. Individual groups of microorganisms showed different sensitivity to the presence of pollution; however, the impact of tar and engine oil mixture was generally more disadvantageous. Presence of contaminants in the soil limited the growth of roots and aboveground parts of spring barley, especially when the dose was $10,000 \mathrm{mg} \mathrm{kg}^{-1} \mathrm{DM}$ soil. The unfavorable impact of waste on photosynthesis efficiency on assimilation pigment synthesis and water content in the plant was recorded.
\end{abstract}

Keywords Plant $\cdot$ Soil $\cdot$ Diesel $\cdot$ Biodiesel .

Microorganisms $\cdot$ Biomass $\cdot$ Gasification

Responsible editor: Philippe Garrigues

Małgorzata Hawrot-Paw

malgorzata.hawrot-paw@zut.edu.pl

1 Department of Agrotechnical Systems Engineering, West Pomeranian University of Technology, Papieża Pawła VI 1, 71-459 Szczecin, Poland

2 Department of Plant Physiology and Biochemistry, West Pomeranian University of Technology, Słowackiego 17, 71-434 Szczecin, Poland

\section{Introduction}

Biomass has always been the main source of energy for people and still is the most widespread of its forms (McKendry 2002). Annual crop of biomass is ca 220 milliard tones (Ren et al. 2009), and it is estimated that it meets world energy needs in 10-14\% (McKendry 2002). Currently, new alternative energy sources are being sought for as well as new technologies of its acquisition. Biomass is not only the green herbaceous material but also waste coming from agriculture and forestry. The ability of their energy utilization corresponds with the principle of balanced development, inscribing itself in so-called circular economy.

There is a number of methods of biomass conversion (thermochemical, biochemical, physicochemical), which allow the release of inherent chemical energy and obtaining this way thermal energy or biofuels. Among the thermochemical methods can be found among others burning, gasification, pyrolysis, and fluidization (Tchabda and Pisupati 2014). Gasification is one of the oldest technologies, which involves the change of fuel content by heating and chemical reaction with oxidant in the conditions of their limited access (which means lack of oxygen relatively to the stoichiometric requirement). In this process, so-called synthesized gas, which consists of $18-20 \%$ of $\mathrm{CO}, 18-20 \%$ of $\mathrm{H}_{2}, 8-10 \%$ of $\mathrm{CO}_{2}$, and 2$3 \% \mathrm{CH}_{4}$ (Bridgwater 2003, Larsen et al. 2003), is primarily formed and furthermore ash and tar as the result of incomplete biomass conversion (Kumar et al. 2009). One of the components formed in the process are hydrocarbons including polycyclic aromatic hydrocarbons. They are a durable organic waste, which is easily tied in the surface layer of the soil (Wilcke 2007), they can accumulate in plants, and in this way, they can incorporate in the food chain, becoming a risk for human health and life. Physiochemical methods used to control this type of pollution often increase the problem 
instead of decreasing or eliminating it (Umanu et al. 2013). Analytical methods are not sufficiently sensitive elements of environmental danger assessment thus the need of monitoring it with living organisms. Especial role in this range is played by microorganisms (Logar and Vodownik 2007) and plants (Hawrot and Nowak 2005).

Gasification of biomass is very interesting alternative for bioenergy production. Syngas can be used in electricity and steam generation, transportation fuels, or hydrogen production. This method helps to reduce dependence of fossil fuels, and it is therefore called environment-friendly technology (Madadian et al. 2014), but we cannot forget that the process of gasification generates by-products, wastes. Their properties depend on the feedstock and the gasification process conditions. The wastes could be toxic or hazardous even if present in amounts that are not detectable by analytical methods. Chemical approach does not allow to identify all the compounds. We need more sensitive indicators of possible pollution customized to the type of contamination. The feasibility of using ecotoxicological tests for this purpose has been determined in this study. The scope of work also included the determination of modification effect of gasification process (filter of combustion engines in the installation was filled or not with engine oil) on the toxicity of wastes. It is very important to know how they will affect the environment because their presence may entail a lot of problems. The applied tests contained biological indicators belonging to various groupsmicroorganisms and plants. These tests could inform about the ability to restore soils their original function as a living environment for other organisms and could also be used to monitor the effectiveness of remedial treatment.

\section{Materials and methods}

\section{Chemicals samples and analysis}

Material for this research has been obtained from the technological process including gasification of wooden chips in order to obtain wood distillation gas, cleaning of the wood distillation gas with the use of filter, and generating electrical energy and heat by use of combustion engine. During this process, ash is produced not only as the main solid waste but also as liquid waste, which is the mixture of water and tarry impurities, is produced. Water and light tar substances are outdropped in the cooler of the pilot installation; however, the residual tares are separated in centrifugal filters of combustion engines, where the material used in research came from. In the first case, the bottom of the filter was filled with engine oil necessary for its proper work (whirling stream of crude gas glances off from the surface of oil, to which impurities with bigger mass attach). After ca $12 \mathrm{~h}$ of work of the system, the initial volume of the engine oil $\left(100 \mathrm{~cm}^{3}\right)$ increased to $500 \mathrm{~cm}^{3}$ due to tar substances, which were precipitated in this filter. In the second case, the bottom of the filter was filled with engine oil due to the assumption that tar substances separated in the cyclone part of the filter, no matter what, will flow to its bottom. After $12 \mathrm{~h}$ of work, their volume was $350 \mathrm{~cm}^{3}$. In this way, two types of research material have been obtained: tar with engine oil in the proportion 4:1 (A) and pure tar (B).

Analysis of the content of examined substances was conducted in Institute of Organic Chemical Technology of West Pomeranian University of Technology in Szczecin. Samples of the material were dissolved in DMF (dimethyl formamide), and in addition, dissolving was supported with ultrasounds. Conditions of conducted analysis: gas chromatograph Trace 2000 GC produced by Thermo, column: TR-WAX produced by Thermo; ( $30 \mathrm{~m}$ long, internal diameter $0.25 \mathrm{~mm}$, film thickness $0.5 \mu \mathrm{m}$ ), carrier gas: helium (constant flow), flow rate of carrier gas: $1.8 \mathrm{~cm}^{3} \mathrm{~min}^{-1}$; mass detector MS Voyager produced by Finnigan (quadrupole); ionization method: electronic; membrane feeder with distribution: split/splitless (SSL); registration and integration: Xcalibur v. 1.2 computer system produced by Finnigan Corporation.

Basic rheological research of tar materials including analysis of dynamic viscosity in temperature range of $5-90{ }^{\circ} \mathrm{C}$ was made. Viscometer Brookfield DV-II+ was used in the research. The sample temperature in the viscometer was kept by a thermostat. The first measurement of dynamic viscosity was started from the lowest temperature and every next at $5{ }^{\circ} \mathrm{C}$. For each measurement point, the temperature was kept by $10 \mathrm{~min}$ to stabilize and measure. Torque of roller in a cylinder filled with samples oil was measured. The resistance of the rotating roller was the scale of the dynamic viscosity. For the adopted measuring temperatures, three times repetition was done based on which the average values of dynamic viscosity ware estimated and next used to determine the charts of viscosity changes in temperature function of sample $\eta=\mathrm{f}(\mathrm{T})$.

\section{Soil}

Soil was collected from the Gumieniecka Plain (Poland, 53 $\left.40^{\prime} \mathrm{N}, 14^{\circ} 47^{\prime} \mathrm{E}\right)$. Soil samples were taken from 0 to $15 \mathrm{~cm}$ of arable-humic horizon. They were air-dried and crushed to pass through a 2-mm mesh sieve. The soil belongs to chernozems, regarding to the particle size composition, represents sandy loam. The basic characteristics of this soil are presented in Table 1.

\section{Experimental design and biological analysis}

Biological research was conducted in loamy sand within two experiments. In the first experiment, the impact of waste from the gasified biomass on soil microorganisms was determined; however, in the second experiment, the evaluated subject was their influence on plants. Within the no. 1 laboratory 
Table 1 Physiochemical properties of the soil

\begin{tabular}{|c|c|c|c|c|c|c|c|c|}
\hline \multicolumn{3}{|c|}{ Percentage of fraction } & $\mathrm{C}$ & $\mathrm{N}$ & $\mathrm{P}$ & $\mathrm{K}$ & $\mathrm{Mg}$ & \multirow[t]{2}{*}{$\mathrm{pH}_{\mathrm{KCl}}$} \\
\hline $2.0-0.05$ & $0.05-0.002$ & $<0.002$ & \multicolumn{2}{|c|}{$\mathrm{g} \mathrm{kg}^{-1} \mathrm{DM}$ soil } & \multicolumn{3}{|c|}{$\mathrm{mg} \mathrm{kg}^{-1} \mathrm{DM}$ soil } & \\
\hline 58.4 & 38.7 & 2.9 & 21 & 1.5 & 120 & 89 & 94 & 6.80 \\
\hline
\end{tabular}

experiment, 1-kg soil samples after determination of current soil moisture by drier-weight method were brought to $50 \%$ capillary water capacity. Next, mixture of tar and engine oil (objects A) or pure tar (objects B) in three doses: 1-100, 21000 , and 3-10,000 $\mathrm{mg} \mathrm{kg}^{-1} \mathrm{DM}$ soil was introduced into the soil. Control object (C) was unpolluted soil. The experiment involved three repetitions for each variant. Samples $(1 \mathrm{~kg}$ of soil with pollution) were placed in polyethylene containers (2.5 1 capacity) and stored for the period of 28 days in the temperature of $20^{\circ} \mathrm{C}$. In the appropriate dates $(1,14,28$ days of incubation), planned microbiological analysis including determination of dynamics of changes in number and activity of soil microorganisms was made. The number of microorganisms was determined by soil-diluted inoculation method, including bacteria on Bunt and Rovira (1955) medium, fungi on Martin (1950) medium, and the order actinobacteria on Cyganov and Žukov (1964) medium, respectively, after 3, 5, and 7 days of incubation in the temperature of $20{ }^{\circ} \mathrm{C}$. Furthermore, the number of copiotrophic microorganisms on NB medium and oligotrophic microorganisms on DNB medium, respectively, after 7 and 14 days of incubation in the temperature of $28^{\circ} \mathrm{C}$ (Ohta and Hattori 1980) was determined. Based on the number of those microorganisms, the $\mathrm{O}: \mathrm{C}$ indicator, which is one of the biological soil balance (WeymanKaczmarkowa 1995) indicators and informs about directions of organic matter conversion, was determined. The results (average from three dates of analysis) were presented as CFU (colonies forming units) recalculated for $1 \mathrm{~g}$ DM soil. Activity of soil microflora polluted with examined substances was determined based on measurement of biomass of living organism content by SIR (substrate-induced respiration) method (Anderson and Domsch 1978). Soil samples (10 g) were enriched with additional $0.3 \mathrm{~g}$ carbon source in the form of glucose and talc mixture (ratio 1:5) and then placed in measuring columns of Ultragas U4S analyzer. The carbon dioxide evolution was measured after $3 \mathrm{~h}$. Microbial biomass was calculated using the equation:

$X=40.04 \times Y+0.37$,

where

$X$ the amount of $\mathrm{C}$ contained in the microbial biomass [mg C $100 \mathrm{~g}^{-1} \mathrm{DM}$ soil]

$Y$ maximum initial production of $\mathrm{CO}_{2}\left[\mathrm{~cm}^{3} \mathrm{~h}^{-1} 1 \mathrm{~g}^{-1} \mathrm{DM}\right.$ soil].
All microbiological designations were made in three repetitions.

Laboratory experiment no. 2 which aimed at evaluation of phytotoxic impact of waste from gasification on growth and development of spring barley conducted with pot method according to the standard (PN-ISO 11269-2-2001). Three pots for each experimental combination were prepared. Ten seeds of spring barley were sown in each pot. Basic biometrical parameters - the height of the part aboveground and length of the root (in $\mathrm{mm}$ ) were determined for all plants from each pot.

After completing the pot experiment, the plant matter was the subject of physiological analysis. Content of chlorophyll "a", "b" and total chlorophyll in leaves was determined with Arnon et al. methods (1956) in Lichtenthaler and Wellburn modification (1983), however, the content of carotenoids with Hager and Mayer-Berthenrath method (1966). For the estimation of assimilation pigment content, a known mass of leaf (about $0.05 \mathrm{~g}$ ) was homogenized in $10 \mathrm{~cm}^{3}$ of $80 \%$ acetone. The homogenate was centrifuged at $2500 \mathrm{~g}$ for $10 \mathrm{~min}$. Optical density of the samples was determined spectrophotometrically with wave length $\lambda=440,645$, and $663 \mathrm{~nm}$ using a spectrophotometer (Marcel Mini). Content of assimilation pigments was expressed in $\mathrm{mg} \mathrm{kg}^{-1}$ fresh mass of the plant. Index of relative water content in leaves (RWC) was determined according to Yamasaki and Dillenburg (1999). Leaf material was weighed to determine fresh weight and placed in distilled water for $24 \mathrm{~h}$, and then turgid weight was recorded. Finally, the samples were dried in an oven at $80^{\circ} \mathrm{C}$ for $48 \mathrm{~h}$ and the dry weights were recorded. RWC was calculated as:

$\mathrm{RWC}=\frac{(\text { fresh weight }- \text { dry weight })}{(\text { turgid weight }- \text { dry weight })} \times 100$

Determination was done in four repetitions.

Using spectrofluorimeter Handy PEA (Hansatech) according to standard procedure of the device, after $20 \mathrm{~min}$ adaptation of leaves to darkness, on six leaves from each experimental variant, measured and calculated were following parameters of fluorescence induction of chlorophyll: $\mathrm{F}_{\mathrm{V}} / \mathrm{F}_{\mathrm{M}}$ - maximum, potential efficiency of photochemical reaction in PS II determined after dark room adaptation, after acceptors reduction in PS II (BolhárNordenkampf and Öquist 1993), $\mathrm{T}_{\mathrm{FM}}$-time of chlorophyll fluorescence increase from the beginning of 
a)

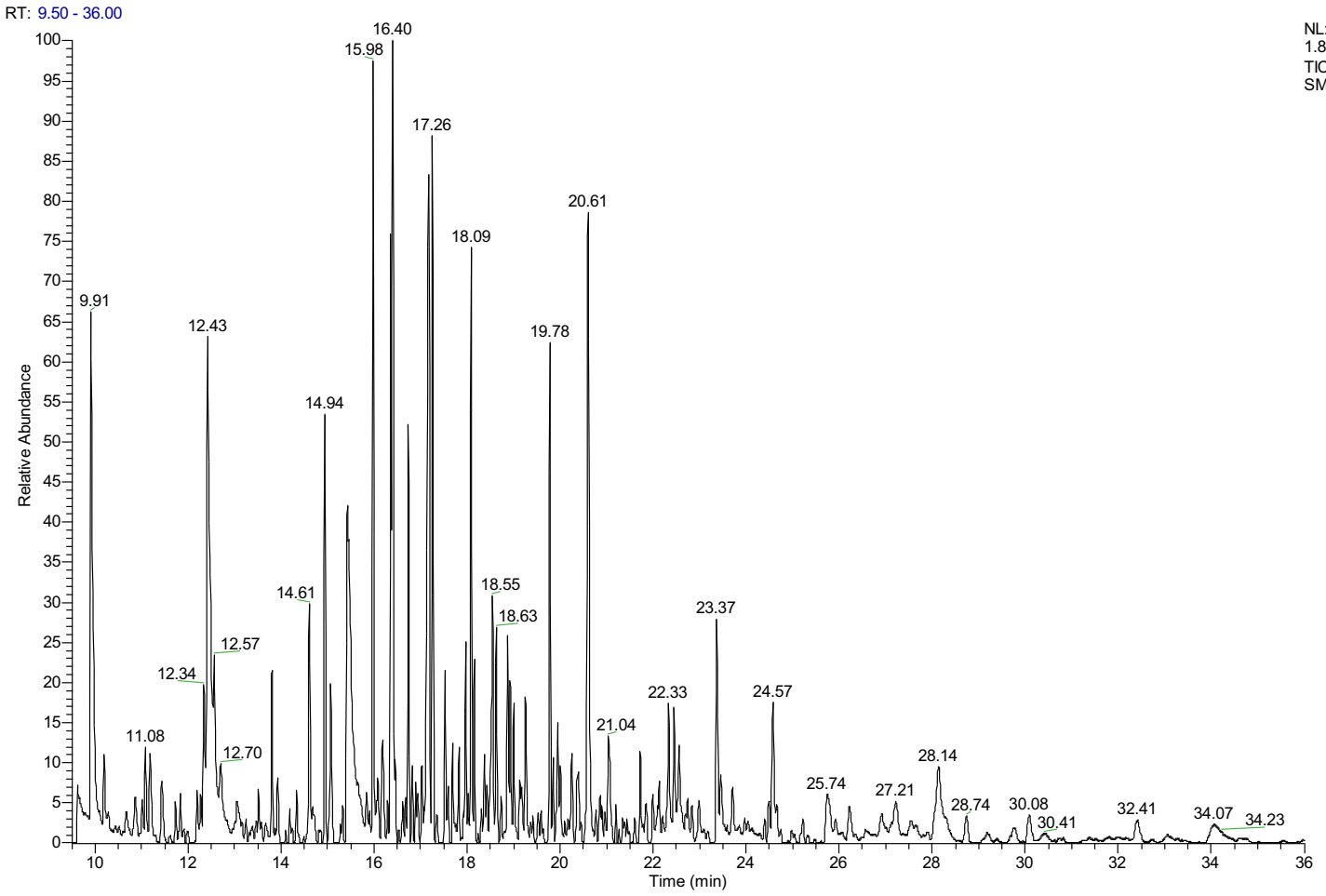

b)

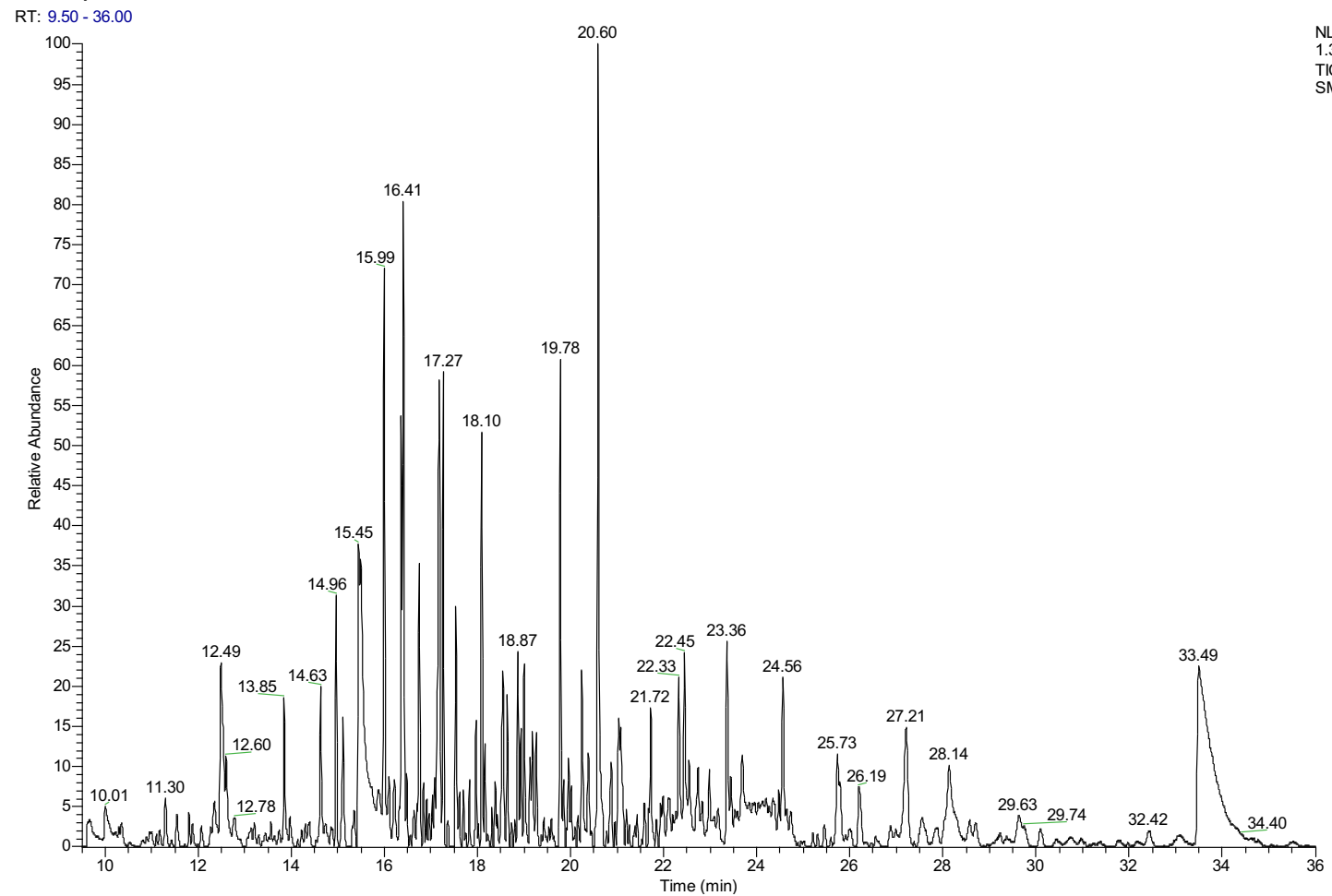

Fig. 1 Chromatographic content of tar and engine oil mixture (a) and tar (b) from the gasification process of biomass 
measurement to reaching maximum $\left(\mathrm{F}_{\mathrm{M}}\right)$, PI-vitality indicator PS II, which concerns general vitality of this system, and area-pool of reduced plastoquinone electron acceptors.

\section{Statistical analysis}

The results of this research have been statistically analyzed using program Statistica ver. 12.0 made by StaSoft Poland. Significance of differences, based on which the average for interaction was allocated to homogeneous groups, was determined by Duncan test on the level of significance $\alpha=0.05$.

\section{Results and discussion}

The results of chromatographic analysis of the substances under research are presented in Fig. 1. In the content of both products, however, with slight difference in content, presence of ingredients typical for tar coming from biomass gasification, among other heterocyclic compounds (phenol, creosols), monochromatic and polycyclic hydrocarbons (Coll et al. 2001), was found. Also acetic acid was noted among the content of tar and engine oil mixture.

In the research concerning dynamic viscosity of the analyzed samples, a very wide range of value variation of this parameter in the assumed range of measuring temperature (Fig. 2) was ascertained. Determined theoretical models of viscosity changes, being the function of temperature, taking into consideration their matching to empiric data $\left(R^{2}\right.$ near 1.0) give base to estimating differences in dynamic viscosity of substances under research, with previously established comparative temperature. For temperature of $20^{\circ} \mathrm{C}$, meeting thermal conditions of the conducted biological research was established that $25 \%$ share of engine oil in tar influenced the decrease of this mixture viscosity by $350,000 \mathrm{mPas}$, that is, by more than $91 \%$ compared to the tar sample not including engine oil. Viscosity of impurities influences their activity in soil, process of soil sorption, and ability to move and also decides about bioavailability. Presence of engine oil in the mixture could have caused disadvantageous changes in soil microstructure (Nazir 2011), thus indirectly influence in negative way on its biological life.

Gasification of biomass is a promising technology of gaining renewable energy; however, waste created in the process including tar might be the cause of natural environment pollution (Mishra et al. 2015). In the evaluation of the effects of their influence, biological research is very helpful, which is a significant element of risk assessment connected with presence of toxic substances in particular elements of ecosystems. Based on chromatographic analysis, no significant differences in tar and its mixture with engine oil content were found; however, the reaction of microorganisms on presence of these pollutants depended not only on the group of microbes but also, in the first place, on the type and dose of pollution. In essential way, it could have been determined by different viscosity of both pollutants. The increase of CFU number, as well as reduction of their number, was observed. It was ascertained that introduction of tar and engine oil mixture (A) to soil caused decrease of number of bacteria, order of actinobacteria, oligotrophic, and copiotrophic microorganisms (Fig. 3). The amount of CFU decreased with the increase of pollution dose; however, significant differences were found only in the presence of the highest dose- $-10,000 \mathrm{mg} \mathrm{kg}^{-1} \mathrm{DM}$ soil. The number of objects in soil polluted with $\operatorname{tar}(\mathrm{B})$ average CFU number was significantly higher than in objects in soil polluted with mixture of products (A). Besides fungi, the quantity of the remaining group of microorganisms in respective objects
Fig. 2 Dynamic viscosity of the tar and engine oil mixture $(A)$ and $\operatorname{tar}(B)$ as function of temperature

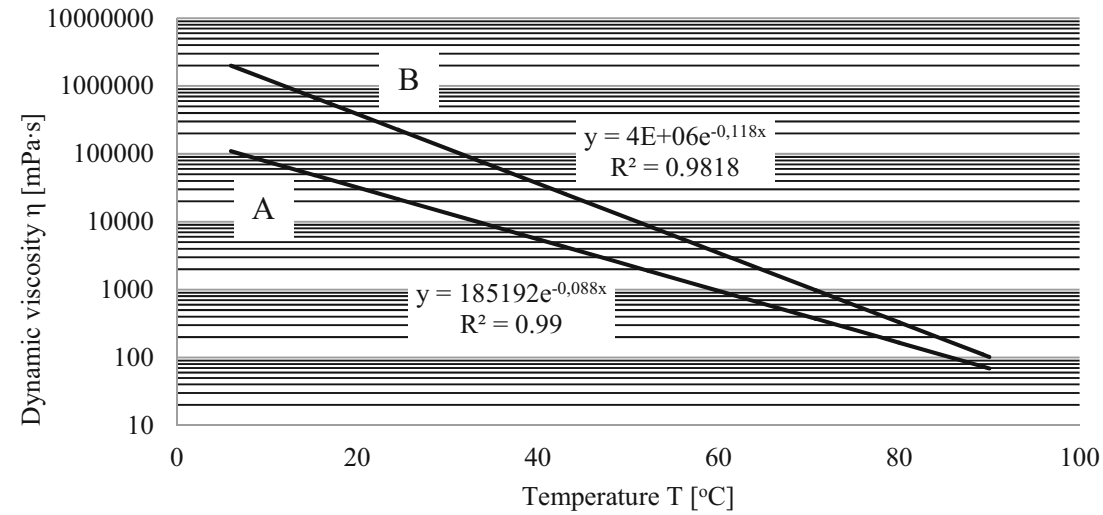


of the experiment was inversely proportional to the level of pollution. Ingredients of the waste, especially hydrocarbons, might be for some organisms a valuable source of carbon and energy, and then their number in the presence of this type of pollution might increase by many times in a short period of time, thus the observed significant stimulation of their growth. Differences in microorganisms' reaction could have also resulted from the different chemical constitution of the examined liquid waste. The mixture contained engine oil, which consisted of, besides hydrocarbons, metalorganic ingredients (Butler and Mason 1997), and what is more significant amount of heavy metals appears in the used oil and the amount of polycyclic aromatic hydrocarbons (Keith and Telliard 1979) increases. Aromatic hydrocarbons may have slowed down microorganisms' growth, and their toxicity grows with molecular mass growth, depending on configuration of benzene rings, substituent presence and position (Šepič et al. 1997). Disadvantageous influence of PAHs on soil microorganisms is confirmed by Hawrot-Paw and Ryłów (2011) research.

The value of coefficient $\mathrm{O}: \mathrm{C}$ for individual objects of the research, which was determined on the base of the number of oligotrophic and copiotrophic microorganisms, contained within the range of 1.42 in soil polluted with tar dose
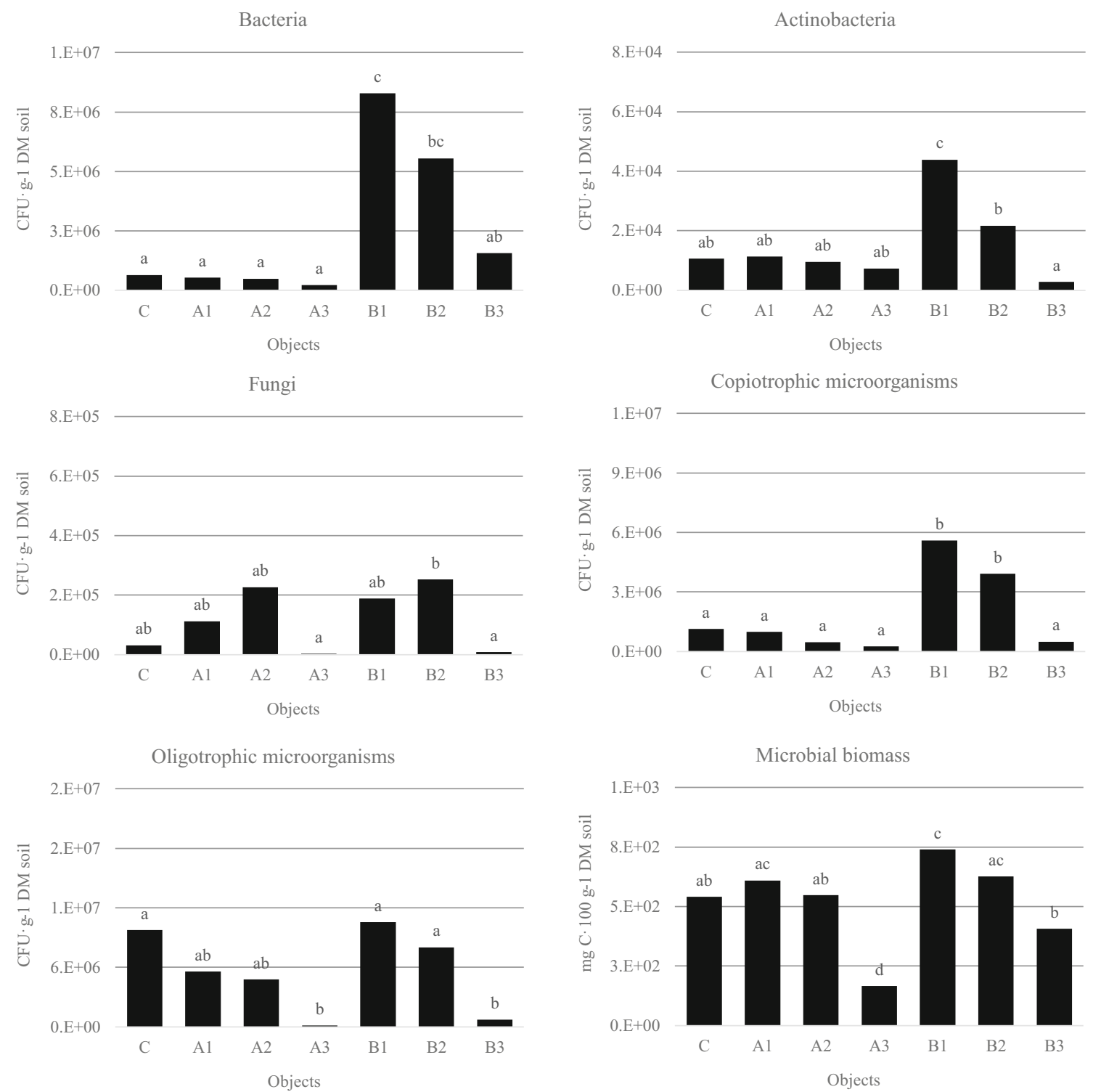

Fig. 3 Average number and activity of microorganisms in individual objects of the experiment (mean over each columns not marked with the same letter is significantly different at $P<0.05$ ) 
$10,000 \mathrm{mg} \mathrm{kg}^{-1} \mathrm{DM}$ soil to maximum 10.37 in the presence of mixture concentration $1000 \mathrm{mg} \mathrm{kg}^{-1} \mathrm{~s}$ DM soil. Superiority of copiotrophic over oligotrophic organisms $(\mathrm{O}: \mathrm{C}=0.45)$ was noted only in object $\mathrm{A} 3$, which can certify disorder in the stable level of organic matter in soil. Oligotrophic organisms often react unfavorably to carbon excess appearing in environment.

Content of microbial biomass is a good indicator of biological activity of the soil (Hawrot-Paw et al. 2010). Waste from the process of gasification in the dose 100 and $1000 \mathrm{mg} \mathrm{kg}^{-1}$ DM soil increased the amount of biomass in comparison to the not contaminated object (Fig. 3). Substantial increase, first of all, has been noticed in B1 object. The increase of the pollution level, in both kinds of waste, caused reduction of microorganisms' activity.

The waste from gasification process had negative impact on biometric parameters of spring barley (Table 2). Conducted statistical analysis confirmed significant impact of the type of pollution and its dose on the height of the aboveground parts of plant as well as length of the root. Smith et al. (2006) examined the impact of the polycyclic hydrocarbons, including those present in the carbon tar, on seven species of grass and legumes. The authors did not ascertain the negative impact of hydrocarbons on germination; however, the presence of pollutants had unfavorable influence on further growth and development of plants, similar to the presented work. Negative impact on the observed results could also be the effect of heavy metals presence released to soil in the mixture of tar and fuel oil. These metals among others aluminum, chromium, cooper, iron, lead, manganese, and nickel, stopped by organic matter of soil, can be absorbed from soil solution by plant roots and cause chlorosis, leave spot disease, necrosis, and lowering of crops (Okonokhua et al. 2007; Adongbede and Sanni 2014).

Table 2 Results of biometrical measurements of spring barley

\begin{tabular}{lcc}
\hline Objects & \multicolumn{2}{c}{ Biometric measurements $[\mathrm{mm}]$} \\
\cline { 2 - 3 } & Lenght of shoots & Root length \\
\hline C & $190^{\mathrm{a}^{*}}$ & $163^{\mathrm{a}}$ \\
A1 & $154^{\mathrm{ab}}$ & $109^{\mathrm{b}}$ \\
A2 & $39^{\mathrm{c}}$ & $7^{\mathrm{d}}$ \\
A3 & $4^{\mathrm{c}}$ & $0^{\mathrm{d}}$ \\
B1 & $189^{\mathrm{a}}$ & $111^{\mathrm{b}}$ \\
B2 & $116^{\mathrm{b}}$ & $41^{\mathrm{cd}}$ \\
B3 & $31^{\mathrm{c}}$ & $8^{\mathrm{d}}$ \\
\hline
\end{tabular}

* Mean over each column not marked with the same letter is significantly different at $P<0.05$
The applied mixture of tar and engine oil, dose of $10,000 \mathrm{mg} \mathrm{kg}^{-1} \mathrm{DM}$ soil, showed toxic influence preventing growth of vegetative part of barley, so the determination of their physiological features was impossible. Statistical analysis showed that mixture of tar and engine oil (object A) used in the dose of $1000 \mathrm{mg} \mathrm{kg}^{-1} \mathrm{DM}$ soil caused lowering of content of all kinds of assimilation pigments (chlorophyll "a", chlorophyll "b", total chlorophyll, carotenoids). In the case of total chlorophyll and carotenoids, the decrease was by $28 \%$ compared with the control (Table 3). Plants from this experimental combination (A2) were characterized with the lowest relative content of water in leaves tissues measured with RWC index. It has also been ascertained that tar pollution in the dose of $10,000 \mathrm{mg} \mathrm{kg}^{-1} \mathrm{DM}$ soil had negative impact on synthesis of all kinds of assimilation pigments, causing lowering of their content in barley leaves from $35.8 \%$ in the case of carotenoids to $39.8 \%$ in the chlorophyll " $b$ " case. Objects from the combination B3 were also characteristic for lower by $10 \%$, compared to control, relative content of water. The research conducted by Hawrot-Paw et al. (2015) has proven the decrease of indicator of RWC in the leaves of pea seeds growing in the fuel oil pollution conditions.

Metabolic process of plants especially sensitive to stress factors activity is photosynthesis. Measurement of chlorophyll "a" fluorescence allows, with high accuracy, to evaluate reaction of plants to photosynthesis process interference by stress factors as well as efficiency of reparation mechanism enabling keeping homeostasis despite unfavorable environmental conditions (Schapendonk et al. 1992, Lichtenthaler 1996, Spáčilová and Šafránkova 2011). Impact of both types of pollution applied in doses 1 and 2 on the value of $\mathrm{TF}_{\mathrm{M}}$ that is on time of increase of chlorophyll fluorescence from the beginning of measuring to gaining maximum was not ascertained. Both types of pollutants applied in these doses lowered the value of system vitality indicator PSII (PI) - Table 3. In the case of polluting soil with tar, dose $10,000 \mathrm{mg} \mathrm{kg}^{-1} \mathrm{DM}$ soil (B3), it was ascertained that it caused decrease of PI indicator decrease by $28.3 \%$ compared to control objects. The number of reduced plastoquinone electron acceptors (area) is one of the best indicators of assimilation apparatus efficiency measured with detection technique and analysis of fluorescence signal of chlorophyll "a." In the conducted research, it was statistically proven that the used types of pollution in dose 1 as well as 2 lowered the value of this parameter, which according to Krause and Weiss (1991) and Kalaji and Łoboda (2007) proves the occurrence of stress phenomenon and blocking the transportation of electrons from reaction centers to plastoquinones. In the objects with combination B3, the value of area indicator was by $16.4 \%$ lower than the noted in control plants. The lowest value 
Table 3 Results of physiological analysis of spring barley

\begin{tabular}{|c|c|c|c|c|c|c|c|c|c|}
\hline Object & $\begin{array}{l}\text { Chlorophyll a } \\
{\left[\mathrm{mg} \mathrm{g}^{-1} \text { fresh mass }\right]}\end{array}$ & $\begin{array}{l}\text { Chlorophyll b } \\
{\left[\mathrm{mg} \mathrm{g}^{-1} \text { fresh mass }\right]}\end{array}$ & $\begin{array}{l}\text { Chlorophyll total } \\
{\left[\mathrm{mg} \mathrm{g}^{-1} \text { fresh mass }\right]}\end{array}$ & $\begin{array}{l}\text { Carotenoids } \\
{\left[\mathrm{mg} \mathrm{g}^{-1} \text { fresh mass }\right]}\end{array}$ & $\begin{array}{l}\text { RWC } \\
{[\%]}\end{array}$ & $\mathrm{T}_{\mathrm{FM}}$ & $\mathrm{F}_{\mathrm{V}} / \mathrm{F}_{\mathrm{M}}$ & PI & $\begin{array}{l}\text { Area } \\
{[\mathrm{bms}]}\end{array}$ \\
\hline $\mathrm{C}$ & $1.231^{\mathrm{b}^{*}}$ & $0.708^{\mathrm{b}}$ & $1.939^{\mathrm{b}}$ & $2.192^{\mathrm{b}}$ & $97.32^{\mathrm{bc}}$ & $261.67^{\mathrm{a}}$ & $0.804^{\mathrm{bc}}$ & $1.355^{\mathrm{b}}$ & $52,531.33^{\mathrm{b}}$ \\
\hline A1 & $1.205^{\mathrm{b}}$ & $0.687^{\mathrm{b}}$ & $1.892^{\mathrm{b}}$ & $2.234^{\mathrm{b}}$ & $96.53^{b c}$ & $281.67^{\mathrm{a}}$ & $0.803^{b c}$ & $1.337^{\mathrm{b}}$ & $45,966.33^{\mathrm{b}}$ \\
\hline $\mathrm{A} 2$ & $0.857^{\mathrm{a}}$ & $0.527^{\mathrm{a}}$ & $1.384^{\mathrm{a}}$ & $1.579^{\mathrm{a}}$ & $79.56^{\mathrm{a}}$ & $248.33^{\mathrm{a}}$ & $0.787^{\mathrm{a}}$ & $0.930^{\mathrm{a}}$ & $29,865.00^{\mathrm{a}}$ \\
\hline A3 & No data & No data & No data & No data & No data & No data & No data & No data & No data \\
\hline B1 & $1.274^{\mathrm{b}}$ & $0.732^{\mathrm{b}}$ & $2.006^{\mathrm{b}}$ & $2.314^{\mathrm{b}}$ & $98.92^{\mathrm{c}}$ & $266.67^{\mathrm{a}}$ & $0.807^{\mathrm{c}}$ & $1.423^{\mathrm{b}}$ & $44,922.33^{\mathrm{b}}$ \\
\hline B2 & $1.204^{\mathrm{b}}$ & $0.697^{\mathrm{b}}$ & $1.901^{\mathrm{b}}$ & $2.155^{\mathrm{b}}$ & $93.51^{\mathrm{b}}$ & $253.33^{\mathrm{a}}$ & $0.795^{\mathrm{ab}}$ & $1.097^{\mathrm{a}}$ & $35,522.83^{\mathrm{a}}$ \\
\hline B3 & $0.767^{\mathrm{a}}$ & $0.426^{\mathrm{a}}$ & $1.193^{\mathrm{a}}$ & $1.407^{\mathrm{a}}$ & $87.52^{\mathrm{a}}$ & $231.60^{\mathrm{a}}$ & $0.740^{\mathrm{a}}$ & $0.971^{\mathrm{a}}$ & $35,566.3^{\mathrm{a}}$ \\
\hline
\end{tabular}

*Mean over each column not marked with the same letter is significantly different at $P<0.05$

of $\mathrm{F}_{\mathrm{V}} / \mathrm{F}_{\mathrm{M}}$ parameter that is maximum potential efficiency of photochemical reaction in PSII (0.787) significantly different from the rest of experimental combinations except combination B2 (tar used in dose $1000 \mathrm{mg} \mathrm{kg}^{-1} \mathrm{DM}$ soil) was ascertained in barley from combination A2 (mixture of tar and engine oil in the dose $1000 \mathrm{mg} \mathrm{kg}^{-1} \mathrm{DM}$ soil). In the case of objects from the combination $\mathrm{B} 3$, the value was even smaller and amounted to 0.717 . Maximum value $\mathrm{F}_{\mathrm{V}} /$ $\mathrm{F}_{\mathrm{M}}$ achieved in the optimum conditions for plant development usually amounts 0.83 . Its decrease certifies the occurrence of stress conditions.

\section{Conclusions}

Significant influence on the size of the soil microorganism groups under investigation and their activity had the type of pollution as well as its dose. For most microorganisms, more unfavorable influence was observed in the presence of mixture of tar and engine oil than only tar itself. Number of microorganisms decreased along with the increase of soil pollution, while in object A, significant differences were observed in the first place in the presence of dose $10,000 \mathrm{mg} \mathrm{kg}^{-1} \mathrm{DM}$ soil. This dose was also significant reduction factor in relation to microorganisms' activity.

The examined impurities had unfavorable impact on growth and development of plants. Together with the increase of dose, independently of the type of pollution, decrease of height of the aboveground parts and length of roots of spring barley was observed. Taking into consideration the parameters of chlorophyll fluorescence induction, it can be ascertained that both types of pollution present in soil in the even smallest dose showed unfavorable influence on photosynthesis efficiency. In higher dose (1000 $\mathrm{mg} \mathrm{kg}^{-1} \mathrm{DM}$ soil), negative influence on synthesis of assimilation pigments and content of water in the plant had first of all the mixture of tar and engine oil (A). In the case of pollution applied in the highest concentration $\left(10,000 \mathrm{mg} \mathrm{kg}^{-1} \mathrm{DM}\right.$ soil), higher toxicity for barley had the mixture of tar and engine oil.

Gasification of biomass, especially the waste, is one of the important methods of energy acquisition from renewable sources. Based on the analysis of acquired results, it was ascertained however that waste generated in this process might have unfavorable impact on the environment. It is advisable to undertake efforts aiming not only at limiting the amount of waste emerging from the technological process but also minimizing their abilities to penetrate the natural environment. In case of pollution, activities aiming at their removing should be undertaken because as it was shown their presence in soil, even in small concentration can negatively influence its biological life. Microorganisms and plants reaction might have been the result of direct toxic impact of pollution contents on microorganisms' cells and plant tissues or might have been the effect of unfavorable physiochemical changes in soil, especially by mixture of tar and engine oil. Bioassays, in contrast to chemical analysis, showed significant differences between of both types of contamination. The selected tests could be useful not only for evaluating the toxicity of by-products but also for other applications, e.g., to assess the bioavailability of organic pollutants, the progress of remediation process.

Open Access This article is distributed under the terms of the Creative Commons Attribution 4.0 International License (http:// creativecommons.org/licenses/by/4.0/), which permits unrestricted use, distribution, and reproduction in any medium, provided you give appropriate credit to the original author(s) and the source, provide a link to the Creative Commons license, and indicate if changes were made. 


\section{References}

Adongbede EM, Sanni RO (2014) Biodegradation of engine oil by Agaricus campestris (a white rot fungus). J Bioremed Biodeg 5:262

Anderson JPE, Domsch KH (1978) A physiological method for the quantitative measurement of microbial biomass in soil. Soil Biol Biochem 10:215-221

Arnon D, Allen MB, Whatley F (1956) Photosynthesis by isolated chloroplast. Biochem Biophys Acta 20:449-461

Bolhár-Nordenkampf HR, Öquist G (1993) Chlorophyll fluorescence as a total in photosynthesis research. In: Hall DO et al (eds) Photosynthesis and production a changing environment. Chapman and Hall, London, pp 193-206

Bridgwater AV (2003) Renewable fuels and chemicals by thermal processing of biomass. Chem Eng J 91:87-102

Bunt JS, Rovira AD (1955) Microbiological studies of some subantarctic soil. J Soil Sci 6(1):119-128

Butler CS, Mason JR (1997) Structure-function analysis of the bacteria aromatic ring hydroxylating dioxygenases. Adv Microb Physiol 38: $47-84$

Coll R, Salvado J, Farriol X, Montane D (2001) Steam reforming model compounds of biomass gasification tars - conversion at different operating conditions and tendency towards coke formation. Fuel Process Technol 74:19-31

Cyganov VA, Žukov RA (1964) Morfologobiochimiciskie osobennosti novowo vida actionomiceta. Mikrobiologija 33(5):863-869

Hager A, Mayer-Berthenrath T (1966) Die Isolierung und quanttaive Bestimung der Carotenoide und Chlorophyll von Blatern, Algen und isolierten Chloroplasten mit Hilfe Dunnschichtchromatographischer Methoden. Planta 69:198-217

Hawrot M, Nowak A (2005) Monitoring of bioremediation of soil polluted with diesel fuel applying bioassays. EJPAU 8(2),\#17. Available online: http://www.ejpau.media.pl/volume8/issue2/art-17.html

Hawrot-Paw M, Ryłów M (2011) Biological activity of soil contaminated with anthracene. Folia Pomer Univ Technol Stetin Agric Aliment Pisc Zootech 290(20):33-40

Hawrot-Paw M, Kamieniecka A, Smolik B (2010) Biological activity of soil contaminated by biodiesel. Environ Prot Eng 36:87-93

Hawrot-Paw M, Wijatkowski A, Mikiciuk M (2015) Influence of diesel and biodiesel fuel-contaminated soil on microorganisms, growth and development of plants. Plant Soil Environ 61(5):189-194

Kalaji MH, Łoboda T (2007) Photosystem II of barley seedlings under cadmium and lead stress. Plant Soil Environ 53:511-516

Keith L, Telliard W (1979) ES\&T special report: priority pollutants: I-a perspective view. Environ Sci Technol 13(4):416-423

Krause GH, Weiss E (1991) Chlorophyll fluorescence and photosynthesis: the basics. Annu Rev Plant Physiol Plant Mol Biol 42:313-349

Kumar A, Jones DD, Hanna MA (2009) Thermochemical biomass gasification: a review of the current status of the technology. Energies 2: $556-581$

Larsen HH, Kossmann J, Sønderberg Petersen L (eds) (2003) Risø energy report 2. New and emerging bioenergy technologies. (Denmark. Forskningscenter Risoe. Risoe-R; No. 1430(EN))
Lichtenthaler HK (1996) Vegetation stress: an introduction to the stress concept in plants. J Plant Physiol 148:4-14

Lichtenthaler HK, Wellburn AR (1983) Determinations of total carotenoids and chlorophyll $\mathrm{a}$ and $\mathrm{b}$ of leaf extracts in different solvents. Biochem Soc Trans 11:591-592

Logar RM, Vodownik M (2007) The application of microbes in environmental monitoring. In: Mendez-Vilas A (ed) Commun Curr Res Educ Top Trends Appl Microbiol 2:577-585

Madadian E, Lefsrud M, Lee CAP, Roy Y (2014) Green energy production: the potential of using biomass gasification. J Green Eng 4:101-116

Martin JP (1950) Use of acid rose bengale and streptomycin in the plate method for estimating soil fungi. Soil Sci 6:215-233

McKendry P (2002) Energy production from biomass (part 1): overview of biomass. Bioresour Technol 83:37-46

Mishra AK, Singh RN, Mishra PP (2015) Effect of biomass gasification on environment. Mesop Environ J 1(4):39-49

Nazir AK (2011) Effect of motor oil contamination on geotechnical properties of over consolidated clay. Alex Eng J 50(4):331-335

Ohta H, Hattori T (1980) Bacteria sensitive to nutrient broth medium in terrestrial environments. Soil Sci Plant Nutr 26:99-107

Okonokhua BO, Ikhajiagbe B, Anoliefo GO, Emede TO (2007) The effects of spent engine oil on soil properties and growth of maize (Zea mays L.) J Appl Sci Environ Manage 11(3):147-152

Ren NQ, Wang AJ, Cao GL, Xu JF, Gao LF (2009) Bioconversion of lignocellulosic biomass is hydrogen: potential and challenges. Biotechnol Adv 27:1051-1060

Schapendonk AHCM, Tonk WJM, van der Putten PEL, Dolstra O, Haalstra SR (1992) Chlorophyll fluorescence: a non-destructive method for detecting damage in the photosynthetic apparatus in plants. Acta Hortic 304(6):61-70

Šepič E, Bricelj M, Leskovšek H (1997) Biodegradation studies of polyaromatic hydrocarbons in aqueous media. J Appl Microbiol 83:561-568

Smith MJ, Flowers TH, Duncan HJ, Alder J (2006) Effects of polycyclic aromatic hydrocarbons on germination and subsequent growth of grasses and legumes in freshly contaminated soil and soil with aged PAHs residues. Environ Pollut 141(3):519-525

Spáčilová V, Šafránkova I (2011) Potential of chlorophyll fluorescence and VIS/NIR spectroscopy measurement use for the detection of nitrogen content and disease infection of apple leaves. Acta Univ Agric et Silvic Mendel Brun 39(6):317-328

Tchabda AH, Pisupati SV (2014) A review of thermal co-conversion of coal and biomass/waste. Energies 7:1098-1148

Umanu G, Akpe AR, Omoikhudu A (2013) Oil degradation assessment of bacteria isolated from used motor oil contaminated soils in Ota, Nigeria. RIJABR 3(4):506-513

Weyman-Kaczmarkowa W (1995) Interdependencies between oligotrophic and copiotrophic bacteria in soils of different mechanical structure. Polish J Soil Sci 29(1):62-72

Wilcke W (2007) Global patterns of polycyclic aromatic hydrocarbons (PAHs) in soil. Geoderma 141(3-4):157-166

Yamasaki S, Dillenburg LR (1999) Measurements of leaf relative water content in Araucaria angustifolia. Revista Brasilleira de Fisiologia Vegetal 11(2):69-75 